\title{
Blended learning i de praktisk-musiske fag set gennem et systematisk litteratur-review
}

\author{
Peter Gundersen, Professionshøjskolen Absalon \\ Anne-Mette Nortvig, Professionshøjskolen Absalon \\ Käte Akselsen, Professionshøjskolen Absalon \\ Karsten Gynther, Professionshøjskolen Absalon
}

\section{Abstract}

Denne artikels formål er at undersøge og diskutere den særlige udfordring det er at undervise i blendede formater i de praktisk/musiske fag. Vi introducerer først til, hvordan begrebet blended learning forstås i et historisk og nutidigt perspektiv. Derefter præsenterer vi resultaterne af et systematisk review, hvor fokus har været på at undersøge undervisning i praktiske færdigheder specifikt i den del af blended learning, der afvikles i online rum. Artiklerne analyseres med henblik på at kunne udpege, hvordan studierne på forskellig vis udfolder og sammensætter underviseres og studerendes roller samt artefakter og teknologier i fysiske og digitale rum, når praktiske færdigheder skal tilegnes. Vi afslutter artiklen ved igen at vende os mod blended learning i fag, hvor der undervises i praktiske færdigheder, men fremdrager her nye måder at forstå og udfolde dette format på med baggrund i indsigterne fra vores review. Forskningsspørgsmålet, artiklen søger at besvare lyder således: Hvordan kan undervisning i praktiske færdigheder medieres, og hvilke konsekvenser har dette for forståelsen af blended learning formater generelt?

\section{Engelsk abstract}

The purpose of this article is to investigate and discuss the challenge of teaching in blended formats in the practical / musical subjects. In the first part of the article, we introduce how the concept of blended learning has been understood historically. Next, we present the results of a systematic review, where the focus has been on examining teaching of practical skills specifically situated in online spaces. The articles are analyzed in order to identify how the studies in different ways unfold and compose the roles of educators and students, as well as artifacts and technologies in physical and digital spaces, when practical skills are to be acquired. We end the article by presenting new ways to understand blended learning based on the insights from our review. 


\section{Introduktion}

"Blended learning" er et omfattende forskningsfelt såvel internationalt som i Danmark. En søgning i

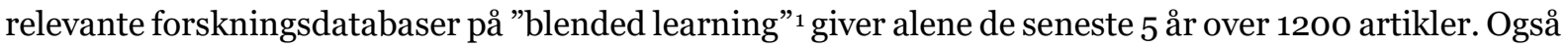
i Danmark har der helt tilbage fra begyndelsen af dette årtusinde været forsket i og publiceret artikler og introduktioner med fokus på blended learning (Georgsen \& Bennedsen, 2004; Gynther, 2005; Dalsgaard 2006; Dalsgaard \& Mikkel, 2007; Bang, Dalsgaard \& Kjær, 2007). Begrebet blev første gang anvendt i pædagogisk sammenhæng i år 2000 (Bernard m.fl., 2014), og allerede i 2006 blev den ofte citerede introduktionsbog "The handbook of blended learning" publiceret (Bonk \& Gramham, 2006). Blot to år efter udkom yderligere en anden indflydelsesrig bog "Blended learning in Higher Education" (Garrison \& Vagughan, 2008). Årene fra år 2000 til år 2010 kan man kalde den "eksplorative periode" i forskning i blended learning. Begrebet var åbent for fortolkninger, og med afsæt i forskellige pædagogiske modeller - mere end ved forskellen på de anvendte teknologier - blev forskellige konkurrerende definitioner lanceret. Fire forskellige forståelser af begrebet kunne i denne periode identificeres (Georgsen \& Bennedsen, 2004; Bernard m.fl., 2014; Atmacasoy \& Aksu, 2018):

* Blended learning er defineret ved en kombination eller mix af forskellige teknologier herunder virtuelle rum, streamet video mv.

* Blended learning er defineret ved et mix af forskellige pædagogiske tilgange - herunder konstruktivisme, behaviorisme og kognitivisme.

* Blended learning er defineret ved en kombination af brug af digitale instruktionsteknologier og klasserumsundervisning.

* Blended learning er defineret ved en kombination af brug af instruktionsteknologier og autentiske opgaver med henblik på at kombinere læring og arbejde.

I samme periode var forskningen også opmærksom på og undersøgte mulighederne i forskellige "presence"-konstellationer for deltagerne (underviser og studerende), idet man var opmærksom på, at begrebet kunne rumme mindst tre modeller (Atmacasoy \& Aksu, 2018):

* Det er de samme studerende, som er til stede i både onlinerummet og i face to face (f2f) rummet

* Online studerende blendes med faf-studerende

* Underviser(en) er multipel - bl.a. kan der være en underviser i f2f-rummet og en anden (eller flere andre) i online-rummet.

Den "eksplorative periode" blev efterfulgt af en periode, hvor begrebets betydninger i højere grad blev ensrettet. Med afsæt i en forskningsworkshop sponsoreret af The Sloan-Consortium definerede en gruppe amerikanske forskere blended learning på følgende måde:

Blended courses integrate online with face to face instruction in a planned, pedagogically valuable manner, and do not just combine but trade-off face to face time with online activity (or vice versa)." (Vignare in Picciano \& Dziuban, 2007 s.38)

${ }^{1}$ Søgningen gik på om "blended learning” indgik i titlen i peer reviewed artikler i følgende databaser: Academic Search Premier, British Education Index, Education Research Complete, Teacher Reference Center og ERIC 
Det blev primært den forståelse af blended learning, der blev den dominerende i årene efter.

Med henblik på at undersøge om ovenstående forståelse af blended learning - som et mix eller blend af klasserumsundervisning og online undervisning - også tegner billedet af forskningen i dag, har vi set nærmere på et udsnit af peer reviewed metaanalyser eller systematiske reviews publiceret med blended learning i titlen de seneste 5 år i en række relevante databaser ${ }^{1}$. Vi har desuden frasorteret de artikler, der ikke indeholdt en definition af blended learning. Søgningen gav 4 artikler, og nedenstående skema giver en oversigt over forfattere og definitioner.

Tabel 1: Oversigt over de 4 definitioner

\begin{tabular}{|l|l|}
\hline Forfattere & Definition af blended learning \\
\hline Bernard m.fl., 2014 & $\begin{array}{l}\text { "the combination of instruction from two historically separate } \\
\text { models of teaching and learning: traditional face-to-face learning } \\
\text { systems and distributed learning systems... in which at least 50 \% } \\
\text { of total course time is face-to-face classroom instruction" }\end{array}$ \\
\hline Boelens, Wever \& Voet, 2017 & "a combination of face to face and online interventions" \\
\hline Vo, Zhu and Diep, 2017 & $\begin{array}{l}\text { "a mix of classroom instruction (i.e., face-to-face) and out-of- } \\
\text { class online learning where the online work substituted for class } \\
\text { time... The course content delivered online ranges between 30 } \\
\text { percent and 79 percent }\end{array}$ \\
\hline Atmacasoy \& Aksu, 2018 & $\begin{array}{l}\text { "any combination of learning delivery methods, including most } \\
\text { often face-to-face instruction with asynchronous and/or } \\
\text { synchronous computer technologies }\end{array}$ \\
\hline
\end{tabular}

Ovenstående skema er en måde at illustrere, at der inden for forskning i blended learning stort set er konsensus om, at blended learning er blended teaching (instruction/delivery) (Gynther, 2012), og at det, som blendes, er en kombination af to undervisningsrum - et fysisk rum og et onlinerum - hvor både underviser og de (samme) studerende er til stede. Hvert rum består af en række "elementer" og "funktioner", som ifølge den nu udbredte forståelse af begrebet blended learning ikke kan adskilles. Grundelementerne i de to undervisningsrum er:

* "underviseren" med hertil tilknyttede velkendte funktioner (formidling og vejledning samt også socialisering, disciplinering og sortering - funktioner som udøves gennem verbale og nonverbale (kropslige) medier),

* rummet - defineret ved et "sted" og den "tid", hvori deltagerne befinder sig i rummet,

* de artefakter/læremidler som befinder sig i rummet samt,

* de studerende med hertil hørende læringsmuligheder (kommunikative og kropslige erkendeformer) samt kollaborative og individuelle læringsstrategier og tilstedeværelsesformer

De fire grundelementer er i denne forståelse af blended learning til stede i begge "rum". Den eneste forskel er, at elementerne i onlinerummet er digitalt medierede. 


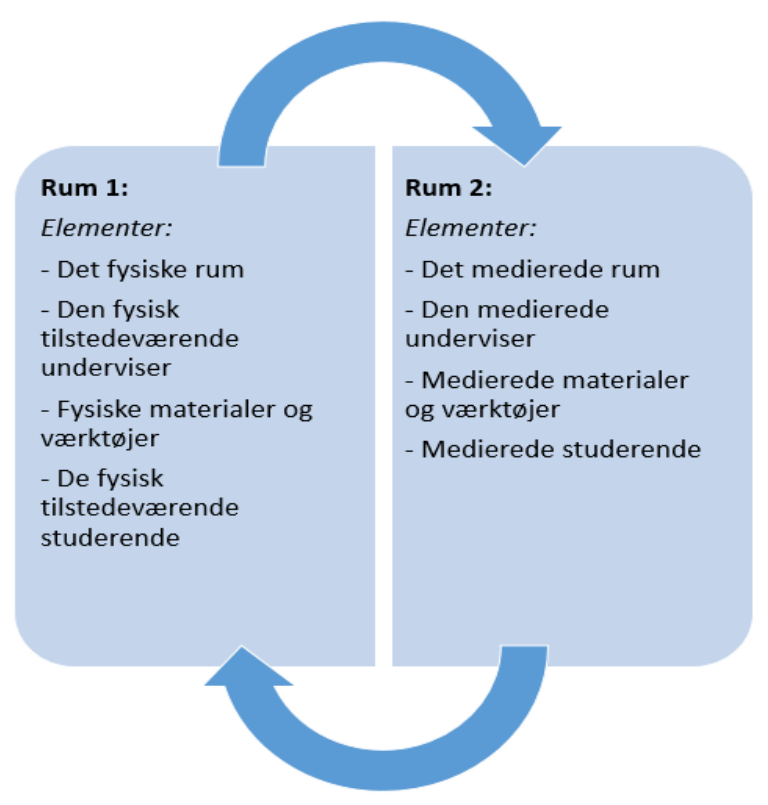

Figur 1 Visualisering af den ovenfor omtalte opfattelse af de to rum i blended learning formatet

Det er denne artikels hypotese, at en sådan forståelse af blended learning i særlig grad er en udfordring for udvikling af blended learning til uddannelse/undervisning i det, som vi i Danmark kalder de praktisk/musiske fag. Disse fag har i særlig grad har været orienteret mod instruktion af og efterfølgende iagttagelse og imitation af en fysisk tilstedeværende "mester" med henblik på umiddelbar korrektion fra denne - ligesom sansemotoriske erfaringer med kroppen og fysiske materialer og værktøjer (artefakter) står centralt i disse fag (Reese, 2016). Alt sammen noget som i den konsoliderede forståelse af blended learning kun kan finde sted i det ene undervisningsrum - f2f-rummet - hvorved onlinerummets fleksible potentialer enten bliver sekundære eller helt udgrænses. Med afsæt i et review af nyere forskningslitteratur undersøgerr vi derfor i denne artikel, hvordan undervisning i praktiske færdigheder kan medieres, og hvilke konsekvenser dette har for forståelsen af blended learning formater generelt.

\section{Metode}

Nedenfor præsenterer vi resultaterne af vores review. Her lader vi os inspirere af bl.a. Creswell's og Hart's (Creswell, 2009; Hart, 2018) metoder til udarbejdelse af et traditionelt systematisk litteraturreview. Meningen med et sådant er at skabe et overblik over et felt gennem tværgående læsninger af artikler publiceret inden for en udvalgt årrække ved at identificere tendenser i de udvalgte artiklers perspektiver og resultater. Trods den begrænsede forskning i feltet (jf. Dolan m.fl., 2015) vil vi med nærværende review forsøge at skabe overblik over de artikler, der har været publiceret om, hvordan undervisning i praktiske færdigheder medieres i praktiske (og praktisk-musiske) fag.

Først udarbejdede vi med udgangspunkt i forskningsspørgsmålet en søgestreng, som kunne afvikles i udvalgte databaser over forskningslitteratur. Idet vi i denne fase havde en eksplorativ tilgang til feltet, valgte vi at inddrage så mange variationer af begreberne som muligt, indenfor de tre hovedområder: online og blended undervisning, forståelse af undervisningsaktiviteter og af praktisk/musiske fag.

Søgestrengen hed derfor: [masterclass OR Vocational education OR Community of practice OR practical skill development OR apprenticeship OR arts in education OR mentoring OR coaching OR situated learning OR field trips OR practical skills OR procedural skills] AND [e-learning OR online learning OR web-based learning OR synchronous OR asynchronous OR video conferenc* OR video-conferenc* OR web conferenc* OR Distance Education OR Virtual OR Massive open online course OR Remote lab] i 
databaserne ERIC, Academic Search Premier, Teacher Reference Center og Education Research Complete i årene 2015-2019.

Denne søgestrategi gav i alt 348 resultater, og for at få så bredt men også så relevant et udvalg af artikler indenfor det for os delvist ukendte felt, valgte vi ikke at indsnævre søgningen gennem nye algoritmer, men derimod at fordele de mange artiklers abstracts mellem os og således håndplukke de i første omgang relevante artikler. I denne proces læste vi artiklernes abstracts i overlap, så ingen læste alle artikler, men alle artikler blev læst af 2 personer. Hermed fik vi dobbelt perspektiv på relevans, og i de tilfælde der ikke var enighed, diskuterede vi os frem til en fælles afgørelse. Vi inkluderede artikler som både fokuserede på undervisning, som foregik i et online format, og hvis mål var udvikling af praktiske færdigheder hos studerende. Levede den enkelte artikel ikke op til disse kriterier, blev den ekskluderet. For eksempel så vi, at en meget stor del af artiklerne nok fokuserede på asynkrone undervisningsformater, men ikke også inkluderede synkrone og/eller f2f-elementer. Dette resulterede $\mathrm{i}$, at kun 82 blev accepterede på den baggrund og gik videre til vores læsning af artiklerne i deres helhed. Imidlertid viste læsningerne, at flere artikler trods lovende abstracts måtte frasorteres pga. manglende relevans i forhold til forskningsspørgsmålet, hvorefter vi endte på 37 artikler, som matchede alle kriterierne. Disse var publicerede fordelt over de fem år på hhv. 8 artikler i 2015, 5 i 2016, 9 i 2017, 12 i 2018 og 3 i 2019.

De i vores review nu inkluderede artikler læste vi igennem og kategoriserede gennem selective coding (inspireret af Corbin \& Strauss, 1990). Denne tilgang til empirien bygger på en konstuktivistisk forståelse af forskning, som ser forskningsresultater opstå i et samspil mellem forskeren og feltet (Charmaz, 2010; 2003). Det var altså os som forskere, der udvalgte kategorierne ud fra forståelsen at "There is no meaningful voice emerging from nowhere" (A. Clarke, 2005, p. 18) og udfra den specifikke interesse $i$ at undersøge undervisning i praktiske fag i online og blendede formater.

Disse kategorier centrerede sig derfor om underviseraktiviteter, studenteraktiviteter, rum, artefakter og teknologi, og vi analyserede dem efterfølgende med særligt henblik på forståelse af (blendede) rum og praktiske færdigheders tilegnelse. Nedenfor redegør vi for disse tematikker og kategorier, og vi diskuterer deres bidrag til besvarelse af vores forskningsspørgsmål.

\section{Empiriske fund fra review'et}

I det følgende redegør vi således med udgangspunkt i de indledningsvist identificerede kerneelementer (se figur 1) en række tematisk opdelte fund fra vores review. Temaerne er 1) rum 2) artefakter og teknologier og 3) undervisere og studerende. I vores senere diskussionsafsnit sætter vi disse tre temaer i relation til undervisning i praktiske færdigheder i blendede formater.

\section{Rum}

18 ud af de til reviewet udvalgte 37 artikler forholder sig specifikt til "rum" (Brinson, 2015; Catalano, 2015; Dolan, Hancock, Wareing, 2015; Hämäläinen \& Cattaneo, 2015; Martin \& Ertzberger, 2016; Reese, 2016; Birt, 2017; Ferrone, Kebodeaux, Fitzgerald \& Holle, 2017; Lara et. al, 2017; Stapleton, Tshida \& Cuthrell, 2017; Berry, 2018; Carmouche, Thompson, Carter, 2018; Faulconer \& Gruss, 2018; Hunna, 2018; Lee, 2018; Moran, 2018; Nikolai, Bennett, Marsk \& Gilson, 2018; Teräs \& Kartoglu, 2018.)

På tværs af artiklerne kan identificeres fire forskellige metaforer eller karakteristika, som definerer artiklens forståelse af rum, som udfoldes her nedenfor. 


\section{De spatiale / temporale rum}

5 artikler refererer direkte til den traditionelle forståelse af blended learning, som en kobling af klasserummet og onlinerummet (Teräs \& Kartoglu, 2018; Lee, 2018; Dolan, Hancock, Wareing, 2015; Hunna, 2018; Berry, 2018). En forståelse som har den konsekvens for tilegnelse af praktiske færdigheder, at onlinerummets funktion bliver at frigøre tid til, at man f2f kan træne praktiske færdigheder (Dolan, Hancock, Wareing, 2015). Den klare adskillelse mellem klasserummet og onlinerummet er dog i opbrud i en enkelt af artiklerne, idet deltagerne i begge rum har adgang til ekspertperformance af en færdighed gennem videooptagelser (Dolan, Hancock, Wareing, 2015) - et eksempel på at underviser og/eller en anden eksperts ekspertise her er blevet medieret gennem en opdeling af den traditionelle mester(lærer) i to funktioner - den instruerende (videoperformance) og den stilladserende (tilstedeværende).

\section{Mixed reality}

5 artikler refererer direkte til rum som modalitet forstået som graden af og formen for mediering af virkeligheden - herunder i hvor høj grad en modalitet opleves realistisk (Nikolai, Bennett, Marsk \& Gilson, 2018; Birt, 2017; Hämäläinen \& Cattaneo, 2015; Faulconer \& Gruss, 2018; Ferrone, Kebodeaux, Fitzgerald \& Holle, 2017). Særligt forskningen i traditionelle og ikke traditionelle science-laboratorier giver et godt overblik over forskellige modaliteter, som kan kombineres i et blended learning-forløb (Faulconer \& Gruss, 2018; Brinson, 2015). Traditionelle "hands on-labs" på uddannelsesinstitutionerne er rum for fysiske eksperimenter med afsæt i fysiske artefakter (materialer og værktøjer). Her er underviser, studerende og artefakter til stede i samme rum. I et "onlinelab" er materialer og værktøjer computermedieret og processer simuleret (virtuelt lab), og underviser og studerende kan enten være i samme rum eller i hvert sit fysiske rum. Underviserfunktionen kan også her være opdelt i to funktioner, idet en række instruktioner kan være medieret og lagt i det virtuelle laboratorium sammen med øvelser med videre. I et "remotelab" foretages virkelige eksperimenter med virkelige artefakter, men den som eksperimenterer, er adskilt fra eksperimenterne. Også her kan underviser og studerende være enten i samme fysiske rum eller i forskellige rum - begge er dog adskilt fra de fysiske eksperimenter. "Mobile labs" er netop mobile laboratorier, som kan tages med ud i felten eller anvendes som "hjemmelaboratorier". Her er underviser og studerende adskilt i hvert sit rum, mens den studerende er i samme rum som de fysiske artefakter, der anvendes (Faulconer \& Gruss, 2018; Brinson, 2015). Ovenstående forskel mellem de forskellige modaliteter er imidlertid under opbrud da traditionelle "hands on-labs" i dag ofte inddrager en vifte af modaliteter, idet en række processer i disse labs er en kombination af fysiske eksperimenter og computermedierede og simulerede processer. På samme måde kan eksperimenter i "hjemmelaboratorier" kombineres med eksperimenter i et online laboratorium (Brinson, 2015).

Den samme udvikling ser man også inden for Technology Enhanced Learning, bl.a. skelner Hämäläinen \& Cattaneo (2015) mellem tre forskellige modaliteter: a) "Technology Enhanced Classroom" - som er et traditionelt klasserum hvor det er muligt at inddrage computermedierede processer og simuleringer i øvelser og opgaver b) "Simuleringer" tilgængelig online og c) "mobil learning" knyttet direkte til læring i arbejdslivet. De tre rum adskiller sig fra hinanden bl.a. i relation til, om underviser og studerende er i samme fysiske rum eller ikke. "Underviser" er dog medieret til stede i alle tre rum, idet den studerende har adgang enten til kodificeret ekspertviden (f.eks. i en simulering) eller gennem medieret tilstedeværelse af sin underviser - hvad der f.eks. er tilfældet i et forskningsprojekt om mobile learning i arbejdslivet (Hämäläinen \& Cattaneo, 2015).

De forskellige modaliteter kan også mikses (blendes), hvilket er tydeligst beskrevet i forskning, som tager afsæt i "mixed reality" tilgange. To af artiklerne har fokus på dette. I et projekt af Nikolai, Bennett, Marsk \& Gilson (2018) mikser man live performance med et virtuelt rum og undersøger potentialet i at videooptage live performance og gøre optagelserne tilgængelige for fælles refleksion i et online community. I et projekt af Birt (2017) kombinerer man potentialet i såvel mobile labs 
(hjemmelaboratorier), augmented reality og simuleringer - med potentialet i fysisk sensomotorisk feedback. I forskningsøjemed er der konstrueret et avanceret læremiddel til en sundhedsuddannelse, hvor den studerende hjemme laver et 3D print (af en hals med diverse funktionsproblemer), som augmenteres ved brug af en i projektet udviklet app, som deltagerne har downloadet til deres mobiltelefon. Der er således tale om en app, hvori såvel den medierede underviser (instruktioner) og proces-simuleringer samt øvelser og opgaver er placeret (Birt, 2017). I projektet blender man herved en række modaliteter, og samtidig deler man underviserfunktionen op i formidlende og stilladserende funktioner, hvor begge dele medieres og integreres i læremidlet. Desuden konstruerer den studerende selv de fysiske artefakter (med afsæt i en instruktion), som betyder, at den studerende og de fysiske artefakter kan befinde sig i samme rum med henblik på at udnytte potentialet i sensomotorisk feedback på den studerendes interventioner med læremidlet - et såkaldt haptisk loop (Birt, 2017).

\section{Læringsrum}

10 artikler refererer direkte til rum forstået som "læringsrum" (Martin \& Ertzberger, 2016; Reese, 2016; Lara et. al, 2017; Stapleton, Tshida \& Cuthrell 2017; Carmouche, Thompson, Carter, 2018; Lee, 2018; Teräs \& Kartoglu, 2018; Moran, 2018; Hämäläinen \& Cattaneo, 2015). Tilsammen lister artiklerne 11 principielt forskellige læringsrum op, som i en blended learning sammenhæng kan kombineres på forskellig måde. De forskellige rum adskiller sig fra hinanden gennem referenceforholdet mellem læringsrummet og arbejdslivets rum (Hämäläinen \& Cattaneo, 2015). Referenceforholdet er graden af lighed mellem et læringsrum og arbejdslivets rum. I hvor høj grad ligner artefakter, processer og relationer mellem underviser og den studerende de artefakter, processer og relationer, der er i den profession, den studerende uddanner sig til (Hämäläinen \& Cattaneo, 2015). Referenceforholdet kan være direkte eller indirekte (Hämäläinen \& Cattaneo, 2015). Læringsrum, som søger at etablere en direkte reference til det professionelle arbejde, forsøger at replikere og mime artefakter, processer og relationer. Læringsrum, som har en mere indirekte reference, er kendetegnet ved artefakter og processer og i visse tilfælde også relationer, som er medierede og simulerede. Flere artikler omtaler referenceforholdet som grader af autenticitet (Martin \& Ertzberger, 2016; Teräs \& Kartoglu, 2018; Moran, 2018) og undersøger, i hvor høj grad digitale teknologier kan understøtte etablering af autentiske læringsrum forstået som en deltageroplevelse af at deltage i en autentisk kontekst, udføre autentiske opgaver, få adgang til ekspert performance, blive coachet af eksperter samt modtage autentisk evaluering (Teräs \& Kartoglu, 2018).

Med afsæt i denne forståelse af referenceforholdet kan man på tværs af artiklerne opliste 11 forskellige læringsrum:

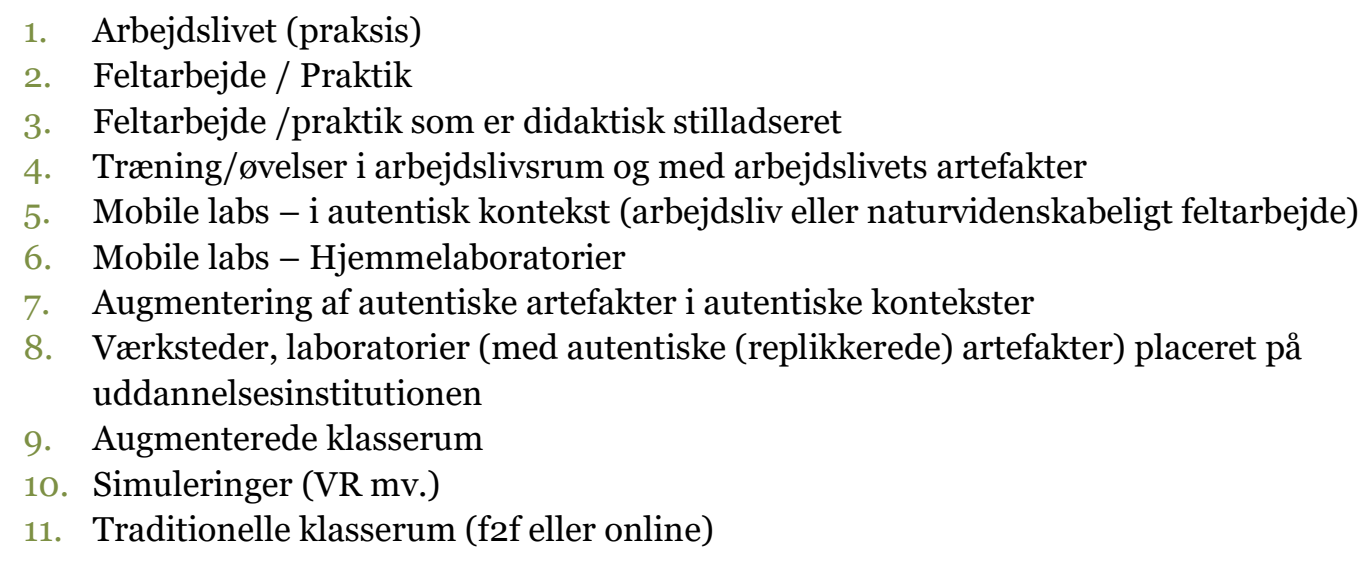

Artiklerne beskriver, hvordan digitale teknologier kan understøtte enten etablering af eller koblinger mellem de forskellige læringsrum. Martin \& Ertzberger (2016)) beskriver, hvordan man etablerer et autentisk læringsrum, som gennem mobile teknologier kobler den studerende med en ekspert. Tre artikler beskriver potentialet i digitalt at koble en mentor (enten en underviser eller en ekspert i 
professionen) med en mentee med henblik på synkron og asynkron coaching (Carmouche, Thompson, Carter, 2018; Stapleton, Tshida \& Cuthrell 2017; Reese, 2016). Fire artikler beskriver potentialet i digitalt at koble uddannelsesinstitutionens læringsrum med arbejdslivets læringsrum (Lee, 2018; Moran, 2018; Hämäläinen \& Cattaneo, 2015; Lara et. al, 2017), og endelig er der en enkelt artikel, som analyserer potentialer i at bruge digitale teknologier til at koble uddannelsesinstitutionens formelle læringsrum med deltagernes uformelle hverdagsliv (Lee, 2018).

\section{Magtrelaterede rum}

En enkelt artikel refererer direkte til rum karakteriseret ved magtrelationer mellem deltagere i forskellige typer af rum (Moran, 2018). Artiklen beskriver potentialet igennem digitale teknologier at etablere "et tredje rum" (third space) - et såkaldt "Digital Third Space". Afsættet er Bhabas (1994) definition af tre rum og deres indbyrdes relation. Det første rum er et kulturelt rum defineret ved originale kulturers egen kultur. Det andet rum er den dominerende kultur herunder deres forsøg på at dominere det første rum - typisk mod deres vilje. Det tredje rum er så en ideal forestilling om etablering af et tredje neutralt rum for læring og udvikling. Med dette ideal kan man med afsæt i digitale teknologier etablere online læringsrum, hvor uddannelsesinstitutionens (dominerende) kultur og deltagernes hverdagserfaringer og kultur kan mødes i et herredømmefrit rum. Moran (2018) beskriver bl.a. et forsøg med etablering af et sådant tredje online rum for lærerstuderende, som her kan møde de elever, de skal i praktik hos før selve praktikopholdet.

\section{Artefakter og teknologier}

Nedenfor samles resultaterne af vores læsning på tværs med henblik på artiklers tematisering af brug af teknologi som sådan og af fysiske artefakter. Vi fokuserer endvidere på brugen og forståelsen af rum i de didaktiske design, der udfoldes i artiklerne.

\section{Få forsøg med inddragelse af fysiske artefakter}

I alle artiklerne spiller teknologien en naturlig rolle for, hvordan undervisningen i det hele taget kan afvikles. Imidlertid er der stor variation i artiklernes tematisering af brugen af teknologi, så flere af artiklerne end ikke nævner, hvilken konkret teknologi, der er tale om (Lee, 2018; McDaniels, Pfund, \& Barnicle, 2016; Reese, 2016), mens andre redegør for og inddrager særligt udviklede teknologier, som er centrale for det didaktiske design (Blackburn, 2017; Chao, Chang, Yang, \& Clark, 2017; Devlin, Lally, Sclater, \& Parussel, 2015; Dolan, Hancock, \& Wareing, 2015; Ferrone, Kebodeaux, Fitzgerald, \& Holle, 2017).

Et for os overraskende fund i vores review af undervisning, der blandt andet fokuserer på læring af praktiske færdigheder, er det manglende fokus på fysiske artefakter, idet kun 3 artikler (Birt, Moore, \& Cowling, 2017; Kalpakis, Palaigeorgiou, \& Kasvikis, 2018; Teräs \& Kartoğlu, 2018) inddrager fysiske artefakter i deres didaktisk design. Hos Kalpakis m.fl. (2018) er artefaktet en kanvas-væg, som danner udgangspunkt for den mixed reality, eleverne inkluderes i i historieundervisningen. Også hos Birt m.fl. (2017) arbejdes der med mixed reality - som nævnt - gennem brug af det 3d-printede menneskehoved med blandt andet en autentisk indre halsregion.

Hos Teräs m.fl. (2018) er artefaktet en digital label, der kan placeres på vacciner, så det kan konstateres, hvorvidt disse har været udsat for for høj varme fx under transport. Denne kan aflæses af den studerende, og det er fortolkningen af disse data, der skal øves i designet. Ingen af artiklerne arbejder med synkrone koblinger mellem fysiske og virtuelle rum/artefakter. 


\section{LMS-brug og forståelse af læring}

I syv af artiklerne afvikles de didaktiske design i traditionelle learning management systems (LMS) som Moodle, Blackboard eller andre lokale undervisningsplatforme. Her anvendes LMS-teknologien især til tilegnelse og diskussion af praktiske færdigheder (Dolan m.fl., 2015; Erol, Upton, \& Upton, 2016; Lara m.fl., 2017; McDaniels m.fl., 2016). Generelt er det mulighederne for både synkron og asynkron undervisning samt udnyttelse af multimodale læremidler, der fremhæves som den helt store fordel ved arbejde i LMS om praktiske færdigheder (Sun, 2018). Fx anvendes hos Lara m.fl. (2017) og Dolan m.fl. (2015) både blogs, wikies, billeder og videoer i Moodle, mens andre bruger den konkrete LMS til undervisning i LMS i sig selv (Berry, 2019). (Her er det undervisere, der skal lære at undervise i online format.) Ofte fremhæver artiklerne mulighederne for at lade de studerende danne læringsfællesskaber (McDaniels m.fl., 2016), så de kan udveksle erfaringer fx fra deres jordemoderpraksis (Erol m.fl., 2016) eller sygeplejerske-job (Lara m.fl., 2017). En enkelt artikel påpeger imidlertid, at undervisning i online eller blendede miljøer i LMS ikke i tilstrækkelig grad understøtter haptisk feedback, hvorfor praktiske og kropslige aktiviteter anbefales afviklet f2f (Dolan m.fl., 2015).

Især Teräs \& Kartoğlu (2018) inddrager en mængde forskellige teknologi i deres EPELA-platform, både Drive, webEx, Skype, virtuelle biblioteker, Flipgrid, videoer, online dagbøger, alt sammen mhp udvikling af færdigheder i og refleksioner over brug af den digitale label til varmemåling.

\section{Teknologier uden direkte kobling til undervisningsinstitutionen}

Flere artikler undersøger enkelt-teknologier, som ikke nødvendigvis inddrages som element på LMS. Blandt andet arbejder Moran (2018) på Slack.com som en læringsomgivelse for virtuel undervisning og samarbejde om skoleundervisning, og generelt arbejder flere af artiklerne (Carmouche, Thompson, \& Carter, 2018; Owen, Whalley, Dunmill, \& Eccles, 2018; Stanley, Serratos, Matthew, Fernandez, \& Dang, 2018; Sun, 2018; Tanis \& Barker, 2017) med synkrone teknologier som Skype og Facetime, som dog også ofte lades understøtte af (delvist) asynkrone teknologier også som GoogleDocs, Dropbox, sociale medier og mail.

Mens Hunma (2018) ser en fordel i at lade studerende arbejde anonymt på en hjemmeside på nettet, finder Dredger m.fl. (2017) i modsætning hertil, at styrken i online læring ligger i fællesskabet og samarbejdet med virkelige mennesker via i dette tilfælde en wiki (her et hold lærerstuderende, der online skal undervise en skoleklasse i at skrive poesi).

\section{Specielle teknologier og deres bidrag til læring}

En stor del af artiklerne placerer sig i kategorien af teknologier, der er specielt udviklede til en særlig uddannelse eller et element her. I denne kategori er mange optagede af at skabe muligheder for læring gennem simulations- og scenariebaseret undervisning. Således ses fx unge mennesker (Devlin m.fl., 2015) udvikle livskompetencer som avatarer i en 3 D-verden, InterLife, apoteker-elever øver sig i beregning af medicindoser gennem MyDispense-software (Ferrone m.fl., 2017), og dansere øver sig i og får løbende feedback på dansekoreografi under brug af MoCap studio-software og hardware (Nikolai, Bennett, Marks, \& Gilson, 2019). Det scenariebaserede fokus gennem brug af særlig teknologi ses hos tre artikler (Blackburn, 2017; Chao m.fl., 2017; Hämäläinen \& Cattaneo, 2015), der bruger teknologien til skabelse af rum, hvori undervisningen kan afvikles, så den simulerer den praksis, de studerende skal udvikle praktiske færdigheder i.

De særlige teknologier skaber også koblinger mellem praksis uden for undervisningsrummet ( $\mathrm{fx}$ kokkepraktiksted (Hämäläinen \& Cattaneo, 2015), gennem mobile learning (Martin \& Ertzberger, 2016) og med henblik på kulturundersøgelser (Hwang, Chang, Chen, \& Chen, 2018). Artiklerne her fremhæver bl.a. særligt mulighederne for refleksioner over praksis som en fordel. 


\section{Fordele og ulemper ved digitale teknologier}

Enkelte af artiklerne fremhæver direkte fordele og/eller ulemper ved at lære praktiske færdigheder i blendede eller online undervisningsformater (Dolan m.fl., 2015; Dredger m.fl., 2017; Erol m.fl., 2016; Ferrone m.fl., 2017; Hunma, 2018; Stanley m.fl., 2018). Således fremhæver Dredger m.fl. (2017), at blog-teknologien lader de studerende fokusere på produktet og praktiske færdigheder til at skrive digte og ikke på personen, der evt. skal læse dem. Stanley m.fl. (2018) finder et større engagement hos de sygeplejestuderende pga. de virtuelle simulations-scenarier, og Ferrone m.fl. (2017) argumenterer, at fordi MyDispense-softwaren kan varieres i det uendelige, kan de studerende øve sig på langt flere simulerede situationer, end det ville være muligt i en praktisk fysisk virkelighed. Endelig finder Hunma (2018), at online undervisning helt generelt er den bedste form for undervisning, fordi forelæsninger kan genses, litteraturen let kan opdateres, sider på nettet hurtigt kan besøges, og at det således overordnet set skaber en mulighed for et "performativt space", hvor studerende kan udfolde sig også på egen hånd.

Enkelte ulemper i at skulle lære praktiske færdigheder i et online miljø findes hos både Erol m.fl. (2016) og Dolan m.fl. (2015). Begge peger de på problematikken med manglende vejledning fra underviserens side. F2f-vejledning, finder Erol m.fl., er nemlig det vigtigste parameter i fastholdelsen af studerende, og når dette ikke er muligt, truer frafald de studerende. Ikke alene manglende f2f-feedback fra underviseren er et problem, finder Dolan m.fl. dog. Også den haptiske respons fra krop og artefakter udgør et problem for læring af praktiske færdigheder og kompetencer finder disse forskere (2015).

Opsamlende i forhold til fysiske artefakter og konkrete digitale teknologier til brug for undervisning i praktiske færdigheder og kompetencer i blendede/online formater kan vi således fremhæve, at vi kun få af artiklerne inddrager fysiske artefakter og at ingen eksperimenterer med praktiske færdigheder i fysiske rum i kombination med online rum. Endvidere ser vi, at selvom der tages udgangspunkt i fordele ved blendede formater som muligheder for studenter-samarbejde, praksisrefleksion og fleksibilitet i tid og sted, så behandler kun få af artiklerne disse særligt i forhold til netop de praktiske færdigheder, der fokuseres på i de forskellige didaktiske design.

\section{Undervisere og studerende}

I det følgende præsenteres vores læsning på tværs af de udvalgte artikler med fokus på undervisernes og de studerendes måder at interagere med hinanden på i blendede formater, hvor praktiske færdigheder er i spil. Som vi var inde på indledningsvist, er der funktioner knyttet til det at være underviser, som der sjældent eksperimenteres med herunder professionel vejledning og feedback. De følgende afsnit stiller skarpt på de studier i vores litteratur, der specifikt har eksperimenteret med at bryde med tanken om blended teaching (forstået primært som instruktion) og i stedet ser på alternative måder, hvorpå de studerende kan modtage vejledning eller få feedback der ikke er afhængig af et fysisk rum og et online rum, der er koblet synkront. De fund, der her præsenteres, repræsenterer dermed i særlig grad forskningsresultater, der bryder med den dominerende forståelse af blended learning.

\section{Coaching og mentoring}

Baseret på Reeves m.fl. (2010) vejledning til autentisk e-læring præsenterer Teräs \& Kartoğlu (2018) i deres artikel 9 principper for design af undervisningsforløb i onlinemiljøer. Tre af disse omhandler adgang til eksperter, rum for refleksion og coaching. Sidstnævnte er ikke et videre udbredt begreb på højere uddannelsesniveauer i Danmark og konnoterer snarere personlig udvikling og terapeutiske forløb. Imidlertid dukker begrebet op i flere af reviewets artikler (Kumar \& Johnson, 2019; Tanis \& Barker, 2017; Carmouche, Thompson \& Carter, 2018; Maul, Berman \& Ames, 2018; Reese, 2016; Stapleton, Tschida \& Cuthrell, 2017). Et andet beslægtet begreb der tydeligt træder frem som en ændret 
underviserrolle er mentoring (Kumar \& Johnson, 2019; Tanis \& Barker, 2017, Reese, 2016; Reese, 2017, McQuade, Davis and Nash 2015).

Tanis og Barker (2017) skelner mellem de to begreber på følgende måde: Coaching refererer til understøttelse af aktiviteter med fokus på konkret udvikling af specifikke færdigheder. Mentoring er derimod en proces, hvor mentor understøtter mentee's personlige og faglige udvikling. Samtidig skelner forfatterne mellem, hvad de anser som en misforstået mentor-mentee relation baseret på vidensoverførsel. I stedet definerer de denne relation som en gensidig proces, hvor begge har interesse i og kan lære af relationen, og hvor viden konstrueres i fællesskab. Mentees interesse er her, at kursusviden transformeres til relevant viden til egen praksis. Mentoren skal dele ressourcer og understøtte transformativ læring i stedet for simpel træning af færdigheder (ibid., 2017).

Mentoring har i onlineformater flere forskellige navne herunder e-mentoring, virtual mentoring, telementoring og online mentoring (Kumar \& Johnson, 2019). Indenfor erhvervelsen af praktiske sygeplejefærdigheder introduceres begrebet "long-arm-mentoring" (McQuade, Davis and Nash, 2015). Begrebet anvendes som en brugbar metafor for enhver mentor-relation, der hovedsageligt finder sted på distancen, og som understøttes af teknologi for at opretholde adgangen. E-mentoring defineres i denne artikel som "et computer-medieret forhold med gensidige fordele mellem en mentor og en protege, der indeholder læring, vejledning, opmuntring, der ofte er grænseløs, ligeværdig og kvalitativt anderledes end traditionel face-to-face mentoring" (Bierema \& Merriam, 2002; McQuade, Davis and Nash, 2015).

Kumar og Johnson (2019) sammenfatter de forskellige bud på online mentorbegreber i to overordnede strategier.

* Praksis-orienteret supervision - hvor mentor deler egen praksis med de studerende

* Relations-orienteret supervision med fokus på en tæt relationsopbygning men ingen fælles praksis

Forfatterne peger på gode resultater med en indledende asynkron feedback efterfulgt af synkrone mentor-sessioner. På samme vis præsenterer Reese (2017) et design i musikundervisningen, hvor mentees optager egen undervisning med henblik på skiftevis synkron (dialogisk) og asynkron (skriftlig) mentoring. I en tidligere artikel skelner Reese (2016) mellem mentoring "inside the action" som handler om at vejlede i undervisning, demonstrere og medundervise og Mentoring "outside the action", der i stedet er centreret om fælles planlægning, debriefing enten før eller efter undervisningen, analyse og refleksion.

I et kritisk perspektiv peger Tanis og Barker (2017) på at dialogen i asynkron refleksiv mentoring med et transformativt sigte i praksis hurtigt kan skifte til simpel efterspørgsel på konkrete svar fra de studerende.

I Carmouche, Thompson \& Carters (2018) artikel følger coaching-faserne: instruktion, observation og feedback. Virtuel coaching ophæver bindingen "f2f", hvilket gør det økonomisk billigere, mindre tidskrævende og mere fleksibelt at coache, og man kan coache studerende/professionelle, som befinder sig andre steder geografisk. Man kan derfor coache regelmæssigt, nå mange forskellige coaching behov og faser i performance hos den professionelle/studerende.

Ifølge forfatterne er det vigtigt, at coachen laver meget engagerede træningssessioner (ibid). Virtuel coaching kan være asynkron (fx via e-mail) - men erfaringen er, at skriftlig asynkron coaching er vanskelig. Virtuel Coaching kan også være synkron. Digitale teknologier indgår på flere måder og den virtuelle coach kan have mange forskellige aktiviteter. Instruktioner kan være asynkrone eller synkrone. Observation kan være asynkron (coachen ser en optaget video) eller synkron (coachen følger en session over live stream). Analyser af studieperformance kan tage afsæt i en optaget session, hvilket til gengæld 
er tidskrævende. Alternativt kan coaching foregå synkront under studenter-performance gennem "BugIn-Ear"-teknologi. Her peger forfatterne på, at coachen skal a) formidle/instruere i effektiv performance, b) personalisere coaching til hver enkelt studerende arbejds- eller studiesitutation og c) give ikke fordømmende men konstruktiv feedback.

Eksemplerne fra artiklerne illustrerer, hvordan der kan eksperimenteres med at skabe rum for refleksion over de studerendes udvikling af praktiske færdigheder gennem forskellige former for asynkron vejledning, og hvordan synkron vejledning i den konkrete praksis kan understøttes ved hjælp af bug-in-ear teknologi.

\section{Forskellige feedbackformer}

En udfordring i relation til coaching og mentoring er, hvorledes og hvornår feedback gives fra en underviseren/coachen/mentoren til kursisten. I modsætning til den refleksive feedbackform, som disse understøtter, tilbyder de resterende artikler en række forskellige bud på feedback. Det drejer sig om umiddelbar underviserfeedback, asynkron feedback på videooptagelser og automatisk feedback fra specialkonstruerede digitale læremidler.

Martin \& Ertzberger (2016) introducerer begrebet "here and now mobile learning”, der har særligt fokus på, at de studerende lærer via mobile teknologier. Filosofien bag dette design er, at konteksten influerer på læring, og at den lærende derfor bør være placeret i selve konteksten, når de praktiske færdigheder erhverves. I artiklen skelnes der mellem tre typer af efterfølgende refleksion: ingen refleksion, selvguided refleksion og refleksion med en virtuel ekspert.

Med samme udgangspunkt i umiddelbar feedback beskriver Del Fatto m.fl. (2016) begrebet "extreme apprenticeship", hvor de studerende selv skal løse en lang række praktiske opgaver. Oplever den studerende, at en opgave er for svær, kan han eller hun bede om vejledning, der dog doseres, således at den kun lige hjælper den studerende videre. I et sådant forløb er det altså den studerende, der i høj grad driver indlæringen af praktiske færdigheder, men med et sikkerhedsnet af "on demand vejledning".

Anderledes forholder det sig med feedback-eksempler taget fra forskning i musikundervisning (Reese 2016, 2017) og koreografi (Nikolai, J., Bennett, G., Marks, S., Gilson, G. 2019). En række studerende optog 30 minutters musikundervisning og delte optagelsen med deres underviser. Efterfølgende afholdt de vejledningssessioner som beskrevet tidligere. Med optagelser af dansesekvenser, hvor underviseren har fokus på at fremprovokere fejl, er det de studerendes opgave selv at få øje på dem og efterfølgende korrigere.

Afsluttende ser vi i artiklerne eksempler på automatisk feedback i online træningsmiljøer, der er specialdesignede med erhvervelsen af særlige praktiske færdigheder for øje. En gruppe mekatronikstuderende fik eksempelvis praktisk erfaring med servostyring i et beskyttet miljø via et programmerbart arbejdsbord (Chinnasamy m.fl., 2018). I et andet studie kan en gruppe studerende gennem et webbaseret kommunikations- og simulationsprogram kaldet Mydispense træne kompetencer i nøjagtig og sikker udlevering af medicin på apoteker (Ferrone m.fl., 2017). I et forsøg på at etablere haptiske, visuelle, og lydmæssige feedback loops for paramedicinstuderende udvikler Birt, Moore og Cowling, (2017) med hjælp af 3D print og augmented reality et design baseret på simulationsøvelser.

\section{Opsamling og diskussion}

I det følgende afsnit opsamler vi indledningsvist den brede vifte af praktiske færdigheder og praksisforståelser artiklerne i reviewet dækker. Herfra diskuterer vi måder at sammensætte de centrale elementer undervisere, studerende, rum, teknologi og artefakter på, som bryder med den dominerende forståelse af blended learning præsenteret indledningsvist. 
I reviewet ses praktiske færdigheder i relation til så forskelligartede praksisser som eksempelvis laboratoriearbejde (Faulconer \& Gruss 2018), forskerpraksis (Kumar \&Johnson 2019), sygepleje, sport og kommercielle færdigheder (McQuade, Davis and Nash 2015), industriel computerstyring (Chinnasamy m.fl., 2018), musikundervisning (Reese 2016, Reese 2017), koreografi (Nikolai, Bennett, Marks \& Gilson 2019), advokatpraksis (Hewitt 2015) og medicindistribution (Ferrone m.fl., 2017).

I artiklerne ses det endvidere, at praktiske færdigheder (practical skills) flere steder - mere eller mindre eksplicit - forstås som en ud af flere elementer i en praksisfunderet handlekompetence (Brinson 2015, Erol m.fl. 2016, Hunma 2018, Hewitt 2015). Eksempelvis beskriver Brinson (2015) i sin undersøgelse af læringsudbytte for henholdsvis "traditionel Lab" og "non traditional lab" 2 , det ønskede "outcome" i form af; viden og forståelse, evne til at stille spørgsmål/forholde sig undersøgende, praktiske færdigheder; opfattelse/perception samt social og videnskabelig kommunikation. Flere artikler bruger færdigheder synonymt med kompetence; Ferrone (2017) taler eksempelvis om virtuel træning af praktiske færdigheder i medicindispensering, som reelt indeholder komplekse praksiskompetencer, der også involverer dialog og vejledning til borgere. Flere steder ses fokus på andre dele af professionskompetencen end praktiske færdigheder. Fx Chao m.fl. (2017), hvis fokus er et webbaseret undervisningsforløb, målrettede nyuddannede sygeplejerskers udvikling af etisk beslutningskompetence samt Hewitt (2015), der studerer et blended learning-format med henblik på advokaters professionsrelevante kompetence i form argumentation, refleksion og problemløsning.

Slutteligt ses praktiske færdigheder i sammenhæng med virtuelle fællesskaber. Virtuelle praksisfællesskaber mødes som grundlag for kollaboration og konstruktivistisk læring den/de fagprofessionelle imellem (Lee 2018, Lara m.fl., 2017). Særligt kan her fremhæves Lara m.fl. (2017), der undersøger videnshåndtering og gensidig kompetenceudvikling i et virtuelt praksisfællesskab mellem 2 forskellige faggrupper i sundhedsvæsenet (praktikere i primær sundhedstjeneste og speciallæger på sygehuset), igangsat med det formål at undgå unødvendige hospitalshenvisninger hos borgere. Her bliver det meningsgivende i professionen en relevant motivationsfaktor for kollaborationen.

Praktiske færdigheder anvendes således både i meget brede forståelser, der også kunne betegnes som kompetence og praksisfællesskaber såvel som i helt snævre fagspecifikke færdigheder. I det følgende afsnit vil vi især fokusere på sidstnævnte når vi med udgangspunkt i et innovationsteoretisk perspektiv vil se nærmere på, hvordan de centrale komponenter sammensættes på nye måder.

\section{Forståelser og koblinger af rum}

"Rum" er i gennemgangen af empirien en central kategori dels med henblik på en kritisk forståelse af det blended learning-begreb, som i dag dominerer forskningslitteraturen, og dels fordi et nyt blik på "rum" kan åbne for andre forståelser af blended learning.

I forsøg med forskellige modaliteter fordobles de studerendes live performance via videooptagelser og gøres derved tilgængelige for refleksion (Nikolai, Bennett, Marsk \& Gilson 2018). Birt (2017) udforsker potentialet i at tildele og opdele funktioner for såvel artefakter som undervisere. Underviserfunktionen opdeles i formidlende og stilladserende funktioner, hvor begge dele medieres og integreres i læremidlet. De studerende konstruerer derefter selv de fysiske artefakter, hvilket betyder, at den studerende og de

${ }^{2} \mathrm{NTL}$ - online simuleringer, remote laboratorie (adgang til virkelige eksperimenter online) og mobile laboratorier 
fysiske artefakter kan befinde sig i samme rum med henblik på at udnytte potentialet i sensomotorisk feedback.

I forhold til referenceforhold eksperimenteres der med funktionen autenticitet i varierende grad, hvilket fører til deltageroplevelser i autentiske kontekster, autentiske opgaver, adgang til eksperter og autentisk evaluering (Martin \& Ertzberger, 2016; Teräs \& Kartoglu, 2018; Moran, 2018). I et læringsperspektiv kan forøgelsen af antal rum ses som et lovende potentiale, bl.a. ved at inddrage arbejdslivets læringsrum (Lee, 2018; Moran, 2018; Hämäläinen \& Cattaneo, 2015; Lara et. al, 2017), deltagernes uformelle hverdagsliv (Lee, 2018) eller et ekstra refleksionsrum (Carmouche, Thompson, Carter, 2018; Stapleton, Tshida \& Cuthrell 2017; Reese, 2016). Et ekstra, tredje, rum gør sig også gældende i forhold til det eneste eksempel på tematikken rum og magtrelationer (Moran 2018). Her eksperimenteres der med afsæt i digitale teknologier i at etablere online læringsrum, hvor uddannelsesinstitutionens (dominerende) kultur og deltagernes hverdagserfaringer og kultur kan mødes i et herredømmefrit rum. Ved hjælp af en fordobling af rum forsøger man her at eliminere en funktion i form af uønsket magtudøvelse.

\section{Nye underviser og studieroller}

Akkurat som i den eksplorative fase af blended learning ser vi i review-litteraturen eksempler på at praksisrummet kobles på undervisningen i praktiske færdigheder. Dette sker både som en modificeret kopi af de eksisterende rum (undervisningsrummet og det digitale rum), og som en tilføjet funktion på det digitale rum, hvormed de studerende kobler sig til underviseren på.

Eksemplerne fra artiklerne illustrerer, hvordan der kan eksperimenteres med at skabe rum for refleksion over de studerendes udvikling af praktiske færdigheder gennem forskellige former for asynkron vejledning, og hvordan synkron vejledning i den konkrete praksis kan understøttes fx ved hjælp af bug-in-ear-teknologi. I sidstnævnte tilfælde kan man iagttage dette som en ny funktion, underviseren har fået tilføjet ved digitalt at kunne følge sine studerende helt ud i praksisrummet.

Eksemplerne på nye former for feedback fra studierne kan ligeledes anskues som formater, der bryder med den dominerende forståelse af blended learning. I eksemplerne med asynkron feedback på videooptaget studieperformance (Reese 2016, 2017, Nikolai, J., Bennett, G., Marks, S., Gilson, G. 2019) har forskerne fordoblet praksisrummet, således at mesteren nemmere kan tilgå det med henblik på feedback. I eksemplet med extreme apprenticeship (Del Fatto m.fl., 2016) har forskerne erstattet f2fundervisningen med praktiske opgaver, hvilket frigiver tid til at underviseren kan give feedback i det øjeblik, den studerende mest har brug det. Slutteligt og i relation til den automatiske feedback har man med designet tænkt i, at læremidler i forhold til visse aspekter af praktiske færdigheder kan overtage mesterens feedback-funktion ved simpelthen at give den automatisk (Chinnasamy m.fl., 2018, Birt, Moore og Cowling 2017, Ferrone m.fl., 2017).

\section{Modificering af teknologier og artefakter}

Som det allerede er fremgået kan "bug in ear" teknologi, videooptagelser og automatiseret feedback gennem specialdesignede læremidler være måder, hvorpå artefakter og teknologi kan muliggøre fremmelsen af praktiske færdigheder blandt de studerende i et blended learning format.

I Birts (2017) artikel ser vi et bud på, hvordan de relevante artefakter fordobles ved hjælp af $3 \mathrm{D}$ print. Problematikken omkring de studerendes manglende adgang til relevante læremidler løses simpelthen ved selv at lade de studerende producere dem der, hvor de befinder sig.

En anden løsningsmodel er at fordoble læringsrummet gennem virtuelle $3 \mathrm{D}$ verdener, hvor de studerende kan simulere udøvelsen af praktiske færdigheder i et sikkert miljø (Devlin m.fl., 2015, 
Ferrone m.fl., 2017). I forlængelse af dette fokuseres der i en række artikler også på udviklingen af scenarier gennem brug af særlig teknologi (Blackburn, 2017; Chao m.fl., 2017; Hämäläinen \& Cattaneo, 2015), således at undervisningen simulerer den praksis, de studerende skal udvikle de praktiske færdigheder i.

\section{Konklusion}

Forskning i, hvordan blended learning kan understøtte tilegnelsen af praktiske færdigheder, orienterer sig mod andre forståelser af blended learning end den, som i dag er mest udbredt. Efter en eksplorativ periode i begyndelsen af dette årtusinde i forståelser og måder at designe blendede forløb er der i forskningen i dag udbredt konsensus om, at blended learning består af et mix af klasserumsundervisning og online undervisning. Denne tilgang er en udfordring for de praktisk-musiske fag, som i særlig grad er orienteret mod undervisningskontekster, der replikerer artefakter og som mimer roller og processer fra den profession, de uddanner til. Udvikling af blendede forløb til de praktisk-musiske uddannelser med det formål at gøre også disse uddannelser mere fleksible og derved tilgængelige for studerende bosat i et stort geografisk område - har derfor typisk handlet om at dele fagets indhold op i to dele. De praktiske færdigheder tilegnes primært f2f i uddannelsesinstitutionens replikerede værkstedsrum med afsæt i en pædagogisk metode, som vægter instruktion - imitation - monitorering og umiddelbar feedback. Onlinerummet anvendes til teoretisk videnstilegnelse. Dette blended learning-design løser imidlertid ikke grundlæggende behovet for træning af grundlæggende færdigheder i disse fag, bl.a. fordi der ofte ikke er tid nok f2f til at dække behovet. Der er derfor behov for andre tilgange til blended learning, som bryder med både den traditionelle forståelse af blended learning, men som også udfordrer gængse faglige selvforståelser i de praktisk-musiske uddannelser. Et kritisk perspektiv på den i forskningen udbredte forståelse af blended learning efterfulgt af et blik på andre typer forskning, som inddrager digitale teknologiers potentialer i tilegnelse af praktiske færdigheder har her vist sig som en perspektivrig måde at forholde sig til ovenstående udfordring. Ikke mindst fordi blended learning forskning i sig selv kun rudimentært har forholdt sig til de praktisk-musiske fag.

Vi på tværs af artiklerne en række nye måder at tænke artefakter, teknologier og ikke mindst deres placering i forskellige typer af rum. Den traditionelle pædagogiske metode i de praktisk-musiske fag nytænkes i en række af de analyserede artikler. Det traditionelle værksted eller laboratorium som uddannelsesinstitutionerne har etableret med henblik på replikation af den praksis de uddanner til, er i flere tilfælde blevet enten medieret eller fordoblet, når vi kigger på de artefakter, som er indeholdt i værkstedet/laboratoriet. Eksempler er her simuleringer og hjemmelaboratorier. I det første tilfælde er artefakter (og processer) medieret og gjort tilgængelig online. I det sidste tilfælde er artefakter fra professionen blevet replikeret i en form, som har betydet, at de studerende kan tilgå og træne praktiske færdigheder hjemme med afsæt i relevante artefakter.

Også underviserrollen og de dertil knyttede funktioner er i en række artikler tænkt på måder der bryder med den dominerende blended learning forståelse. Ligesom den gængse forestilling om, at underviser og de studerende skal være i samme fysiske rum i forbindelse med instruktion og coaching er blevet udfordret. Vi ser i flere artikler, at underviserfunktioner er delt op og medieret. Særligt underviserens formidlende og instruerende funktion er gjort tilgængelig i en medieret form. Men også typiske arbejdsformer i de praktisk-musiske fag som knytter sig til f2f monitorering og feedback er blevet medieret gennem en adskillelse af underviser og studerende i to forskellige rum, hvilket man bl.a. ser i former som virtuel coaching og e-mentoringforløb. 


\section{Referencer}

Generelle:

Atmacasoy, A., \& Aksu, M. (2018). Blended Learning at Pre-Service Teacher Education in Turkey: A Systematic Review. Education and Information Technologies, 23(6), 2399-2422.

Bang, J., Dalsgaard, C., \& Kjær, A. (2007). Beyond blended learning! Undiscovered potentials for e-learning in organizational learning. E-learning Papers.

Barak, M. (2004). Systematic Approaches for Inventive Thinking and Problem-Solving: Implications for Engineering Education. In: Int. J. Engng Ed. Vol. 20, No. 4, pp. 612-618.

Boelens, R., De Wever, B., \& Voet, M. (2017). Four key challenges to the design of blended learning: A systematic literature review. Educational Research Review, 22, 1-18.

Bernard, R., Borokhovski, E., Schmid, R., Tamim, R., \& Abrami, P. (2014). A meta-analysis of blended learning and technology use in higher education: from the general to the applied. Journal of Computing in Higher Education, 26(1), 87-122.

Bhabha, H. K. (1994). The location of culture. New York, NY: Routledge.

Bonk, C. J., \& Graham, C. R. (Eds.). (2006). The handbook of blended learning: Global perspectives, local designs. San Francisco, CA: Pfeiffer

Charmaz, K. (2003). Grounded theory: Objectivist and constructivist methods. In N. K. Denzin, \& Y. S. Lincoln (Eds.), Strategies of qualitative inquiry (2nd ed., pp. 249-291). Thousand Oaks, CA: Sage Publications.

Charmaz, K. (2010). Grounded theory: Objectivist and constructivist methods. In W. Luttrell (Ed.), Qualitative educational research: Readings in reflexive methodology and transformative practice (pp. 183-207). New York: Routledge.

Clarke, A. (2005). Situational analysis: Grounded theory after the postmodern turn. London: Sage.

Corbin, J. M., \& Strauss, A. (1990). Grounded theory research: Procedures, canons, and evaluative criteria. Qualitative Sociology, 13(1), 3-21.

Creswell, J. W. (2009). Research Design: Qualitative, Quantitative, and Mixed Method Approaches (Third edition). Thousand Oaks, California: SAGE.

Dalsgaard, Christian (2006b). Kan blended learning overskride e-læringens begrænsninger? - Lederuddannelse som blended learning. Center for It og Læring. http://old.imv.au.dk/forskning/cil/seminarer/organisatorisk.html/Kan_blended_learning_overskride_elaeringens_begraensninge r.pdf (9. januar, 2007).

Dalsgaard, Christian \& Godsk, Mikkel. (2007). Transforming traditional lessons into problembased blended learning: Experiences and challenges. Open learning, Vol. 22, No. 1, p. $29-42$.

DeSanctis, G., and R.B., Gallupe, (1987). A foundation for the study of group decision support systems, Management Science, Vol 33, no. 5, May 1987, p. 589-609

Garrison, D. R., \& Vaughan, N. D. (2008). Blended learning in higher education: Framework, principles, and guidelines. San Francisco, CA: Jossey-Bass.

Georgsen, M. (2004). Kvalitet og fleksibilitet i netstøttet læring: en indledning. I M. Georgsen, \& J. Bennedsen (red.), Fleksibel læring og undervisning: erfaringer, konsekvenser og muligheder med ikt (s. 9-23). Aalborg: Aalborg Universitetsforlag.

Gynther, K. (2005). Blended learning - IT og læring i et praktisk og teoretisk perspektiv. København: Unge Pædagoger.

Gynther, K. (2012). Blended learning. In: Rasmussen, J. (red.). Pædagogiske teorier. 5. udgave. Værløse: Billesø \& Baltzer.

Hart, C. (2018). Doing a Literature Review: Releasing the Research Imagination. London: SAGE.

Johansen, R. (1988). Groupware: Computer Support for Business Teams, Free Press, New York.

Vignare, K. (2007). Review of Literature Blended Learning: Using ALN to Change the Classroom - Will it Work? In: Picciano, Anthony G. og Dziuban, Charles D. (ed.) Blended Learning - Research Perspectives. USA, SloanC.

Vo, H. M., Zhu, C., \& Diep, N. A. (2017). The effect of blended learning on student performance at course-level in higher education: A meta-analysis. Studies in Educational Evaluation, 53, 17-28.

Yao, C. (2018). How a Blended Learning Environment in Adult Education Promotes Sustainable Development in China. Australian Journal of Adult Learning, 58(3), 480-502.

Zhou, M., \& Li, Z. (2019). Blended mobile learning in theatre arts classrooms in higher education. Innovations in Education \& Teaching International, 56(3), 307-317. 
Specifikke referencer, som er inkluderet i review'et:

Archer, C., \& Kelen, C. (2015). Dialogic pedagogy in creative practice: a conversation in examples. Pedagogy, Culture \& Society, 23(2), 175-202. https://doi.org/10.1080/14681366.2014.932301

Berry, S. (2019). Professional development for online faculty: instructors' perspectives on cultivating technical, pedagogical and content knowledge in a distance program. Journal of Computing in Higher Education, 31(1), 121-136. https://doi.org/10.1007/s12528-018-9194-o

Birt, J., Moore, E., \& Cowling, M. (2017). Improving paramedic distance education through mobile mixed reality simulation. Australasian Journal of Educational Technology, 33(6), 69-83. https://doi.org/10.14742/ajet.3596

Blackburn, G. (2017). A university's strategic adoption process of an PBL-aligned eLearning environment: an exploratory case study. Educational Technology Research \& Development, 65(1), 147-176. https://doi.org/10.1007/s11423-016-9472-3

Brinson, J. R. (2015). Learning outcome achievement in non-traditional (virtual and remote) versus traditional (hands-on)laboratories: A review of the empirical research. Computers \& Education 87 (2015) 218-237.

Carmouche, M., Thompson, J., \& Carter, L. (2018). Effects of Professional Development and Videoconferencing on the Increase of Opportunities to Respond and the on-Task Behavior of Students with Emotional Behavior Disorders. Journal of Information Technology Education, 17, 127-157. https://doi.org/10.28945/4060

Chao, S.-Y., Chang, Y.-C., Yang, S. c., \& Clark, M. j. (2017). Development, implementation, and effects of an integrated web-based teaching model in a nursing ethics course. Nurse Education Today, 55, 31-37. https://doi.org/10.1016/j.nedt.2017.04.011

Chinnasamy, J., Ramesh Babu, K. S., Chenniappan, M., \& Rathinasamy, P. (2018). A workbench for motion control experiments using programmable automation controllers in industrial automation laboratory at Kongu Engineering College. Computer Applications in Engineering Education, 26(3), 566-576. https://doi.org/10.1002/cae.21908

Del Fatto, V., Dodero, G., \& Gennari, R. (2016). How measuring student performances allows for measuring blended extreme apprenticeship for learning Bash programming. Computers in Human Behavior, 55, 12311240. https://doi.org/10.1016/j.chb.2015.04.007

Devlin, A. M., Lally, V., Sclater, M., \& Parussel, K. (2015). Inter-Life: a novel, three-dimensional, virtual learning environment for life transition skills learning. Interactive Learning Environments, 23, 405-424. https://doi.org/10.1080/10494820.2013.768271

Dolan, E., Hancock, E., \& Wareing, A. (2015). An evaluation of online learning to teach practical competencies in undergraduate health science students. Internet \& Higher Education, 24, 21-25. https://doi.org/10.1016/j.iheduc.2014.09.003

Dredger, K., Nobles, S., \& Martin, J. M. (2017). Digital Poetry Practicum: Preservice English Language Arts Teachers' Dispositions of New Literacies. Journal of Literacy \& Technology, 18(1), 157-203.

Erol, R., Upton, P., \& Upton, D. (2016). Supporting completion of an online continuing professional development programme for newly qualified practitioners: A qualitative evaluation. Nurse Education Today, 42, $62-68$. https://doi.org/10.1016/j.nedt.2016.04.005

Faulconer, E. K., \& Gruss, A. B. (2018). A Review to Weigh the Pros and Cons of Online, Remote, and Distance Science Laboratory Experiences. International Review of Research in Open \& Distance Learning, 19(2), 155168. https://doi.org/10.19173/irrodl.v19i2.3386

Ferrone, M., Kebodeaux, C., Fitzgerald, J., \& Holle, L. (2017). Implementation of a virtual dispensing simulator to support US pharmacy education. Currents in Pharmacy Teaching \& Learning, 9(4), 511-520. https://doi.org/10.1016/j.cptl.2017.03.018

Hewitt, A. (2015). Can you learn to lawyer online? A blended learning environment case study. Law Teacher, 49(1), 92-121. https://doi.org/10.1080/03069400.2014.991484

Hunma, A. (2018). "Students Make History Every Day Just by Sitting on These Steps": Performative Spaces and Re-Genring in the South. Education as Change, 22(1), 1-25. https://doi.org/10.25159/1947-9417/706

Hwang, G.-J., Chang, S.-C., Chen, P.-Y., \& Chen, X.-Y. (2018). Effects of integrating an active learning-promoting mechanism into location-based real-world learning environments on students' learning performances and behaviors. Educational Technology Research \& Development, 66(2), 451-474. https://doi.org/10.1007/s11423-017-9567-5

Hämäläinen, R., \& Cattaneo, A. (2015). New TEL Environments for Vocational Education - Teacher's Instructional Perspective. Vocations \& Learning, 8(2), 135-157. https://doi.org/10.1007/s12186-015-9128-1

Kalpakis, S., Palaigeorgiou, G., \& Kasvikis, K. (2018). Promoting Historical Thinking in Schools through Low Fidelity, Low-Cost, Easily Reproduceable, Tangible and Embodied Interactions. International Journal of Emerging Technologies in Learning, 13(12), 67-82. https://doi.org/10.3991/ijet.v13i12.8728 
Kumar, S., \& Johnson, M. (2019). Online mentoring of dissertations: the role of structure and support. Studies in Higher Education, 44(1), 59-71. https://doi.org/10.1080/03075079.2017.1337736

Kyungsun Park. (2015). Instructional Design Models for Blended Learning in Engineering Education. International Journal of Engineering Education, 31(2), 476-485.

Lara, B., Cañas, F., Vidal, A., Nadal, N., Rius, F., Paredes, E., ... Mauricio, D. (2017). Knowledge management through two virtual communities of practice (Endobloc and Pneumobloc). Health Informatics Journal, 23(3), 170-180. https://doi.org/10.1177/1460458216639739

Lee, K. (2018). Everyone already has their community beyond the screen: reconceptualizing online learning and expanding boundaries. Educational Technology Research \& Development, 66(5), 1255-1268. https://doi.org/10.1007/s11423-018-9613-y

Martin, F., \& Ertzberger, J. (2016). Effects of reflection type in the here and now mobile learning environment. British Journal of Educational Technology, 47(5), 932-944. https://doi.org/10.1111/bjet.12327

McDaniels, M., Pfund, C., \& Barnicle, K. (2016). Creating Dynamic Learning Communities in Synchronous Online Courses: One Approach from the Center for the Integration of Research, Teaching and Learning (CIRTL). Online Learning, 2O(1), 1-20. https://doi.org/10.24059/olj.v20i1.518

McQuade, S., Davis, L., \& Nash, C. (2015). Positioning Mentoring as a Coach Development Tool: Recommendations for Future Practice and Research. Quest (oo336297), 67(3), 317-329. https://doi.org/10.1080/00336297.2015.1048810

Moran, C. M. (2018). Learners Without Borders: Connected Learning in a Digital Third Space. Contemporary Issues in Technology \& Teacher Education, 18(2), 9-9.

Nikolai, J. R. A., Bennett, G., Marks, S., \& Gilson, G. (2019). Active Learning and Teaching through Digital Technology and Live Performance: "Choreographic Thinking” as Art Practice in the Tertiary Sector. International Journal of Art \& Design Education, 38(1), 137-152. https://doi.org/10.1111/jade.12181

Owen, H., Whalley, R., Dunmill, M., \& Eccles, H. (2018). Social Impact in Personalised Virtual Professional Development Pathways. Journal of Educators Online, 15(1), 63-75. https://doi.org/10.9743/JEO2018.15.1.9

Reese, J. (2016). Virtual Mentoring of Preservice Teachers. Journal of Music Teacher Education, 25(3), 39-52. https://doi.org/10.1177/1057083715577793

Reese, J. (2017). An Exploration of Interactions Between Virtual Mentors and Preservice Teachers. Contributions to Music Education, 42, 201-222. https://doi.org/10.2307/26367443

Stanley, M. J., Serratos, J., Matthew, W., Fernandez, D., \& Dang, M. (2018). Integrating Video Simulation Scenarios into Online Nursing Instruction. Journal of Nursing Education, 57(4), 245-249. https://doi.org/10.3928/01484834-20180322-11

Stapleton, J., Tschida, C., \& Cuthrell, K. (2017). Partnering Principal and Teacher Candidates: A Virtual Coaching Model Co-Teaching in Clinical Practice View Project Virtual Coaching of Teacher Candidates View project. Journal of Technology and Teacher Education, 4(1).

Sun, S. Y. H. (2018). Student configuration and place-making in fully online language learning. Computer Assisted Language Learning, 31(8), 932-959. https://doi.org/10.1080/09588221.2018.1466808

Tanis, H., \& Barker, I. (2017). E-Mentoring at a Distance: An Approach to Support Professional Development in Workplaces. Turkish Online Journal of Distance Education (TOJDE), 18(3), 135-155.

Teräs, H., \& Kartoğlu, Ü. (2018). Authentic learning with technology for professional development in vaccine management. Australasian Journal of Educational Technology, 34(3), 15-29. 


\section{Forfattere}

\section{Peter Gundersen}

Lektor

Professionshøjskolen Absalon

Center for Skole og Læring, Forskningsmiljøet Digitale Læringsmiljøer og Didaktisk Design

\section{Anne-Mette Nortvig}

Lektor, ph.d.

Professionshøjskolen Absalon

Center for Skole og Læring, Forskningsmiljøet Digitale Læringsmiljøer og Didaktisk Design

\section{Käte Akselsen}

Lektor

Professionshøjskolen Absalon

Center for Skole og Læring, uddannelseskoordinator for læreruddannelsen som e-læring
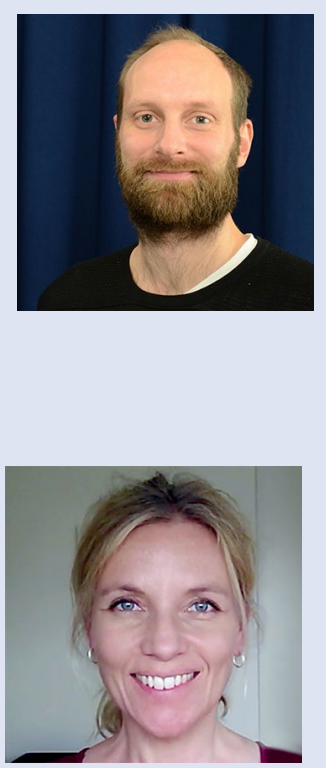

\section{Karsten Gynther}

Docent

Professionshøjskolen Absalon

Leder af forskningsprogrammet Digitale læringsmiljøer og

Didaktisk design
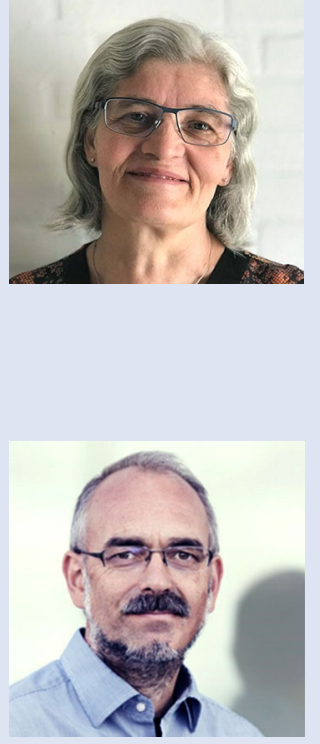